\title{
The anatomy of Cochlespira Conrad (Gastropoda, Conoidea, Turridae) with a description of a new species from the Southeastern coast of Brazil
}

\author{
Luiz Ricardo L. Simone ${ }^{1}$
}

\begin{abstract}
The anatomy of Cochlespira elongata, a new species from continental slope of São Paulo coast, Brazil, is described. This analysis shows some interesting characters in the foregut, with rhynchodeal walls muscular and free from the haemocoel and insertion of venom gland in mid region of the esophagus; in the osphradium, with bilobed right filaments; and in the penis, with a complex arrangement of structures in the tip. A complementary description of Cochlespira radiata (Dall, 1889a) from Florida, USA, is also given, for a better comparison between both species.

KEY WORDS. Gastropoda, Conoidea, Turridae, Cochlespira radiata, systematics
\end{abstract}

The anatomy of species of the genus Cochlespira Conrad, 1865 [type species Pleurotoma cristata Conrad, 1847; = Ancistrosyrinx Dall, 1881; Coronasyrinx Powell, 1944] has not been studied up to now. The foregut characters of some Cochlespirinae, however, are summarized by TAYLOR et. al. (1993), an important paper which revised the higher taxa classification of the Conoidea, based on characters of the shell, operculum and foregut anatomy.

Several specimens belonging to the genus Cochlespira were collected in the dredges of the "Projeto Integrado" developed by Instituto Oceanográfico da Universidade de São Paulo (IOUSP). The present study of these specimens complements the paper of TAYLOR et. al (1993), giving anatomical description of specimens of the type genus of the subfamily Cochlespirinae Powell, 1942.

The determination at specific level of these specimens, using data from the literature (DALL 1889a,b; WARMKE \& ABBOTT 1961; ABBOTT 1974; RIOS 1975, 1985,1994 ) is uncertain between Cochlespira radiata (Dall) and an undescribed species. The doubt was only resolved, in favour of the second determination, comparing these specimens from São Paulo coast, Brazil, with specimens from Florida region, USA, region of the type material of $C$. radiata. Although the description of C.radiata given by DALL (1889a: 78) is very good, a complementary description of this species is necessary for a better comparison with the species described herein.

\section{MATERIAL AND METHODS}

The specimens of C. elongata collected in dredges by R.V. "Prof. W. Besnard" of IOUSP, were fixed in 70\% ethanol and deposited in Museu de Zoologia da Universidade de São Paulo (MZUSP) collection.

1) Museu de Zoologia, Universidade de São Paulo. Caixa Postal 42694, 04299-970 São Paulo, São Paulo, Brasil.

E-mail: Irsimone@usp.br 


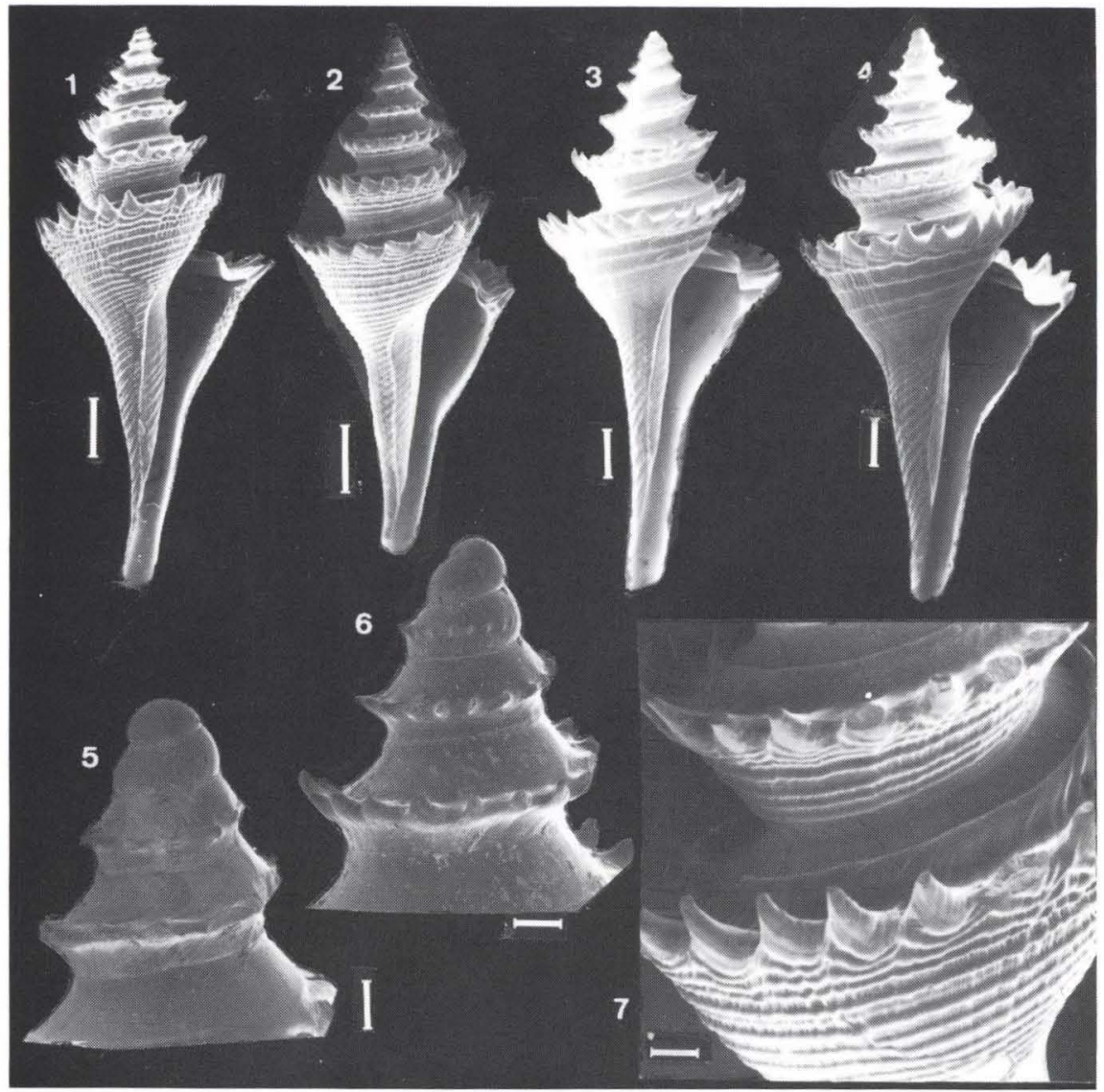

Figs (1-7) Cochlespira spp. shells in SEM. (1) C. elongata, frontal view of paratype MZUSP 28112, scale: $2 \mathrm{~mm}$; (2) C. elongata, frontal and a little apical view of paratype MZUSP 28111 , scale: $2 \mathrm{~mm}$; (3) and (4) two specimens of C. radiata (USNM 412324) in frontal view, scales: $1 \mathrm{~mm}$; (5) detail of the protoconch and first teleoconch whorl of $C$. elongata, scale: $200 \mu \mathrm{m}$; (6) the same for $C$. radiata, scale: $200 \mu \mathrm{m}$; (7) detail of the shell sculpture of the penultimate and last whorls in dorsal view of the C. elongata paratype MZUSP 28111 (fig. 2), scale: 500 $\mu \mathrm{m}$.

Twenty specimens were dissected by standard techniques, the shells were decalcified in Railliet-Henry fluid. Some of them were dehydrated in ethanol series, stained in carmine, cleared and fixed in creosote. The morphology of the anterior region of the digestive system of three specimens of $C$. elongata was studied also by serial sections, after removal from the head-foot, was dehydrated in ethanol series, embedded in paraffin and sectioned at $8 \mu \mathrm{m}$. Sections were stained with Mallory's stain. Shells, radulae and opercula were also examined by SEM in the "Laboratório de Microscopia Eletrônica do Instituto de Biociências da USP". All drawings were made with the aid of a camera lucida. 
The study on $C$. radiata is based on five lots with 150 shells, courtesy of the National Museum of Natural History (USNM), Smithsonian Institution, USA; from these the dry soft parts (last whorl only) were extracted from four specimens, rehydrated with a solution of $70 \%$ ethanol with 5-6 drops of 5\% KOH for $24 \mathrm{~h}$, and afterwards examined as above (except serial sections).

Measures were made with pachymeter, width is the specimen in frontal view and excluding the spines. The following specimens were measured: $C$. radiata: USNM 412341 ( 2 specimens), USNM 412359 (14 specimens), USNM 412324 (10 specimens), USNM 412296 (4 specimens) and USNM 412360 (16 specimens); $C$. elongata: MZUSP 28110 to 28114 (32 specimens), MZUSP 28117 (1 specimen), MZUSP 28116 (2 specimens), MZUSP 28115 (3 specimens).

Conchological and anatomical terminology is based on MARCUS \& MARCUS (1960) and TAYLOR et. al. (1993). Systematics is based on TAYLOR et. al. (1993).

Abbreviations used in the text: (ac) aperture of the capsule gland, (ag) albumen gland, (al) anal slit, (an) anus, (ao aorta, (au) auricle, (bc) bursa copulatrix, (bt) buccal tube, (ca) odontophoral, (cg) capsule gland cartilages, $(\mathrm{cm})$ columellar muscle, (ef) mantle fold of the keel, (ey) eye, (ft) foot, (gd) duct to digestive gland, (gi) gill, (gs) glandiform structure, (ig) ingesting gland, (ip) inner preputial structure, (ki) kidney, (mb) mantle border, (mv) muscular bulb, (nr) nerve ring, (oc) operculum, (od) odontophore, (oe) esophagus, (om) odontophoral muscles, (op) outer preputial structure, (os) osphradium, (ov) oviduct, (pb) proboscis, (pe) penis, (ps) penial spermoduct, (pt) prostate, (pv) pallial oviduct, (ct) ctenidial vein, ( $\mathrm{rd}$ ) rhynchodeal wall, (ro) rhynchostome, (rp) receptaculum seminis, (rs) radular sac, (rt) rectum, (sd) duct of salivary glands, (sg) salivary glands, (si) siphon, (sp) rhynchostomal sphincter, (st) stomach, (te) tentacle, (tg) tegument, (tp) terminal pouch, (vd) vas deferens, (ve) ventricle, (vg) venom gland.

\section{SYSTEMATICS}

\section{Cochlespira elongata sp.n.}

Figs $1,2,5,7,9,11-22,27$

Ancistrosyrinx elegans; Rios, 1970: 129, pl. 48 (non Dall, 1881).

Cochlespira elegans; Rios, 1975: 128, pl. 39, fig. 570.

Cochlespira radiata; Rios, 1985: 134, pl. 46, fig. 607.--Rios, 1994: 164, pl. 54, fig. 743 (non Dall, 1889)a.

Types. Holotype MZUSP 28110; paratypes: MZUSP 28111, 28112 and 28113, 1 specimen each; MZUSP 28114, 50 specimens, all these from type locality;

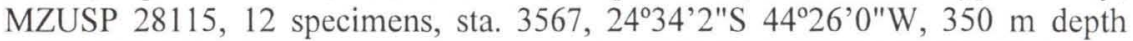

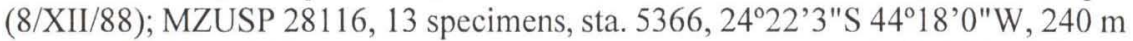
depth (7/XII/88); MZUSP 28117, 8 specimens, sta. 5365, 24⒉ $5^{\prime} 0^{\prime \prime S} 44^{\circ} 16^{\prime} 5^{\prime \prime} \mathrm{W}$,

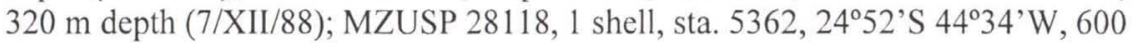

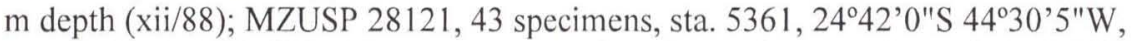
$320 \mathrm{~m}$ depth (6/XII/88). Museu Oceanográfico da Fundação Universidade de Rio Grande, MORG 32290, 2 specimens from type locality; Museu Nacional do Rio de Janeiro, MNRJ 7161; 2 specimens from type locality; USNM 886325, 2 specimens from type locality. 


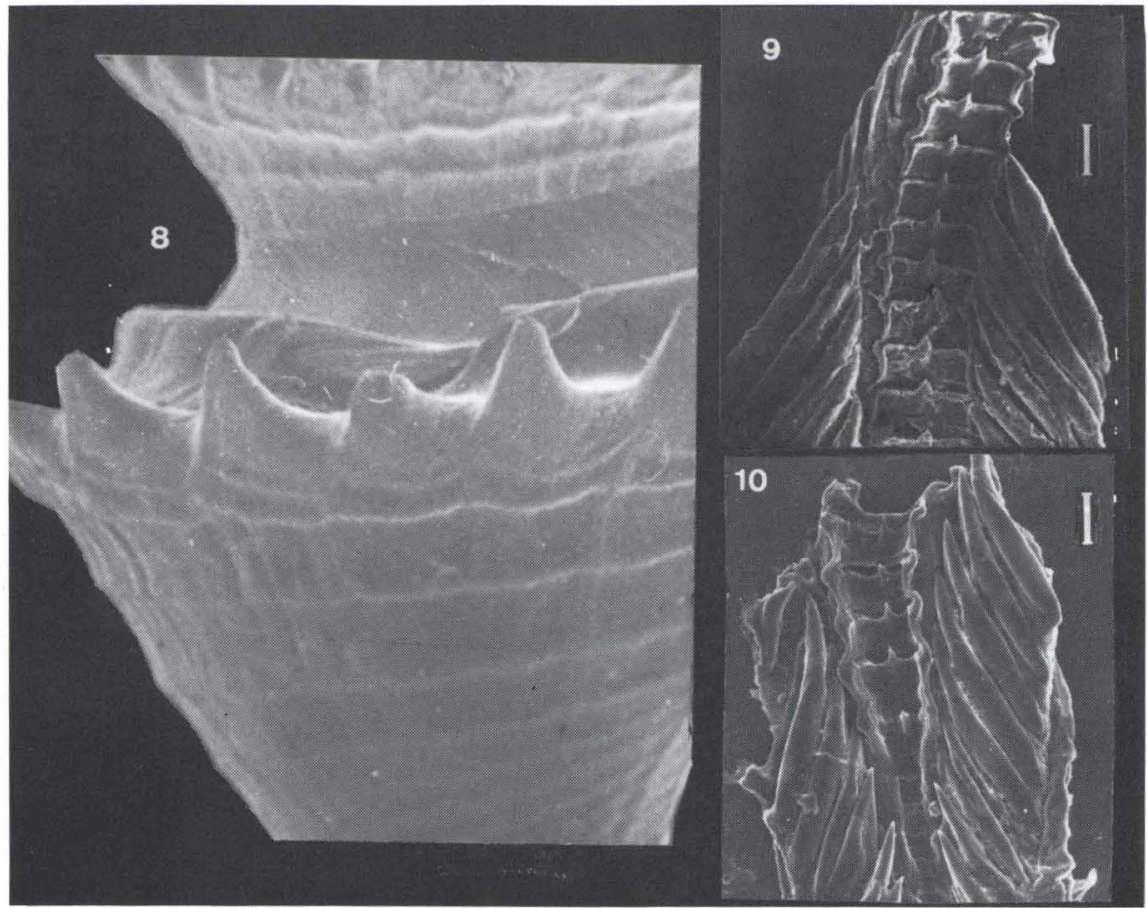

Figs 8-10. Cochlespira spp. in SEM. (8) Detail of the shell sculpture of the penultimate and last whorls in dorsal view of C. radiata specimen USNM 412341 (fig. 3); (9) radular teeth of $C$. elongata, scale: $20 \mu \mathrm{m}$; (10) radular teeth of $C$. radiata, scale: $20 \mu \mathrm{m}$.

Type locality. Brazil, São Paulo State, off Ubatuba, $24^{\circ} 31^{\prime} 0^{\prime \prime S} 44^{\circ} 28^{\prime} 0^{\prime \prime} \mathrm{W}$, 250 m depth (8/XII/1988).

Diagnosis. Shell very long, length almost three times the width; spines of keel up turned; sculpture between posterior suture and keel a spiral lamella marking a unevenness in shell surface; sculpture between keel and canal a series of isometric and uniform cords, aperture moderately narrow. Osphradium right filaments bilobed. Rhynchodaeum walls free from haemocoel, insertion of venom gland in mid region of esophagus. Penis tip with a giandiform structure surrounded by two preputial structures.

Description. Shell. Of medium size (up to $37 \mathrm{~mm}$ ), elongate fusiform, with tall spire and long canal (Figs 1,2), of homogeneous pale-cream to pale-brown color. Some specimens with two broad pale bands encircling shell base and canal, and narrow pale brown longitudinal streaks. Length almost three times the width (length/width ratio $=2.45-2.85-3.38$ ) (Fig. 27). Protoconch of 1.5 smooth, glossy whorls (Fig. 5). Teleoconch up to 9 whorls, angulated by a keel initially in mid region of whorls (Figs 2,5), gradually becoming proportionally near posterior suture. Sculpture between keel and posterior suture possessing a spiral, tall and median lamella, more conspicuous in last whorls, making small uneven (Fig. 7), finishes in anal sinus of outer lip. Keel bearing short, triangular and flattened spines, rather regularly spaced, up and slightly outer turned (Figs 1, 2, 7), about 23 on 
body-whorl. Sculpture between keel and adjacent anterior suture or canal (in body-whorl) a series of spiral regular and isometric cords (Figs 1, 2, 7). Aperture moderately narrow, about half of total spire length. Outer lip notched for a conspicuous anal sinus and keel. Inner lip covered by thin and glossy callus. Canal long, about same length as spire, rather straight and opened.
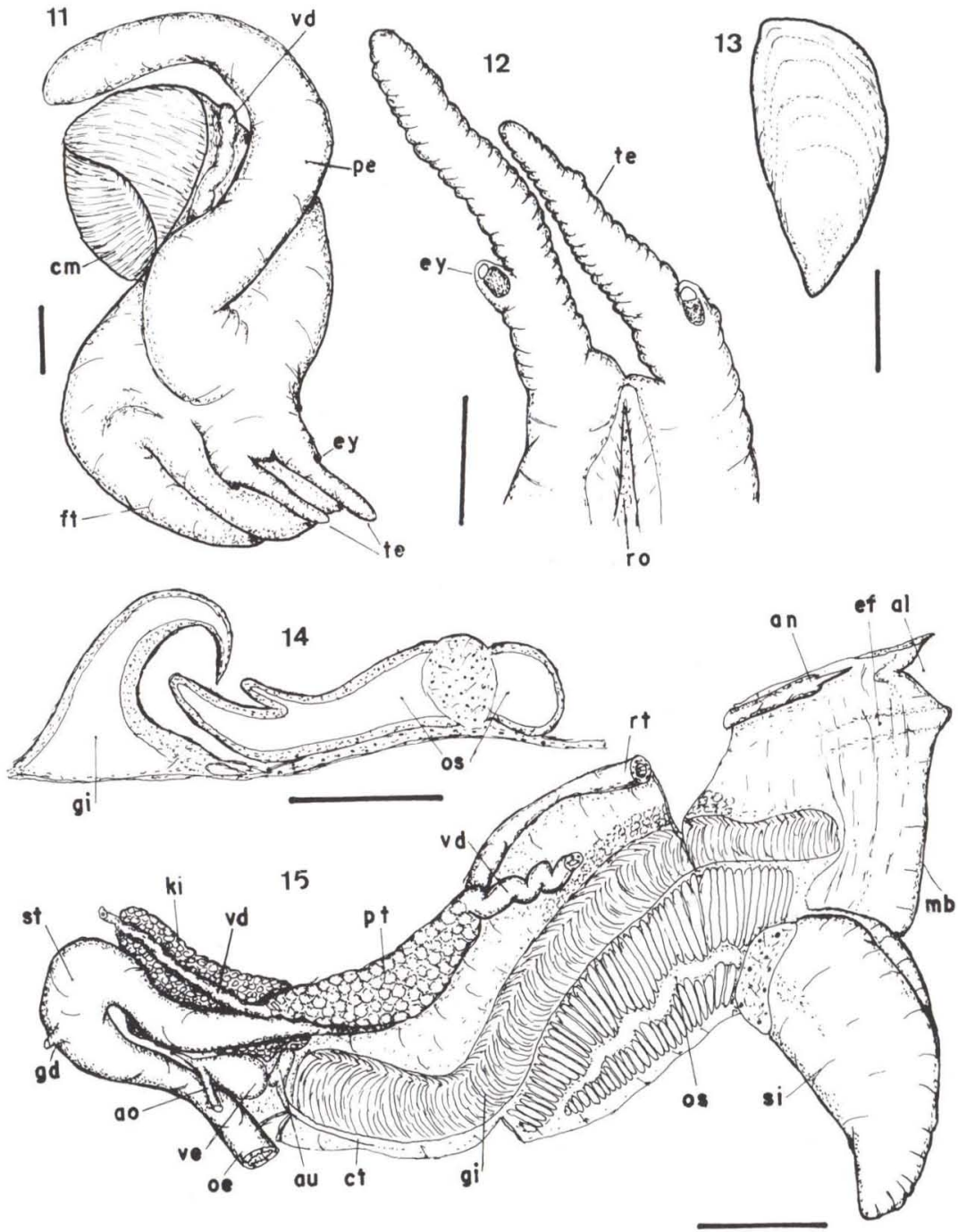

Figs 11-15. Cochlespira elongata anatomy. (11) Dorsal view of the head-foot complex of a male, scale: $1 \mathrm{~mm}$; (12) ventral view of the head, foot removed, scale: $0.5 \mathrm{~mm}$; (13) operculum, external view, scale: $1 \mathrm{~mm}$; (14) a leaflet of the gill and of the osphradium, from they mid regions, scale: $0.5 \mathrm{~mm}$; (15) ventral view of the pallial organs and region of the penultimate whorl of a male, scale: $1 \mathrm{~mm}$. 


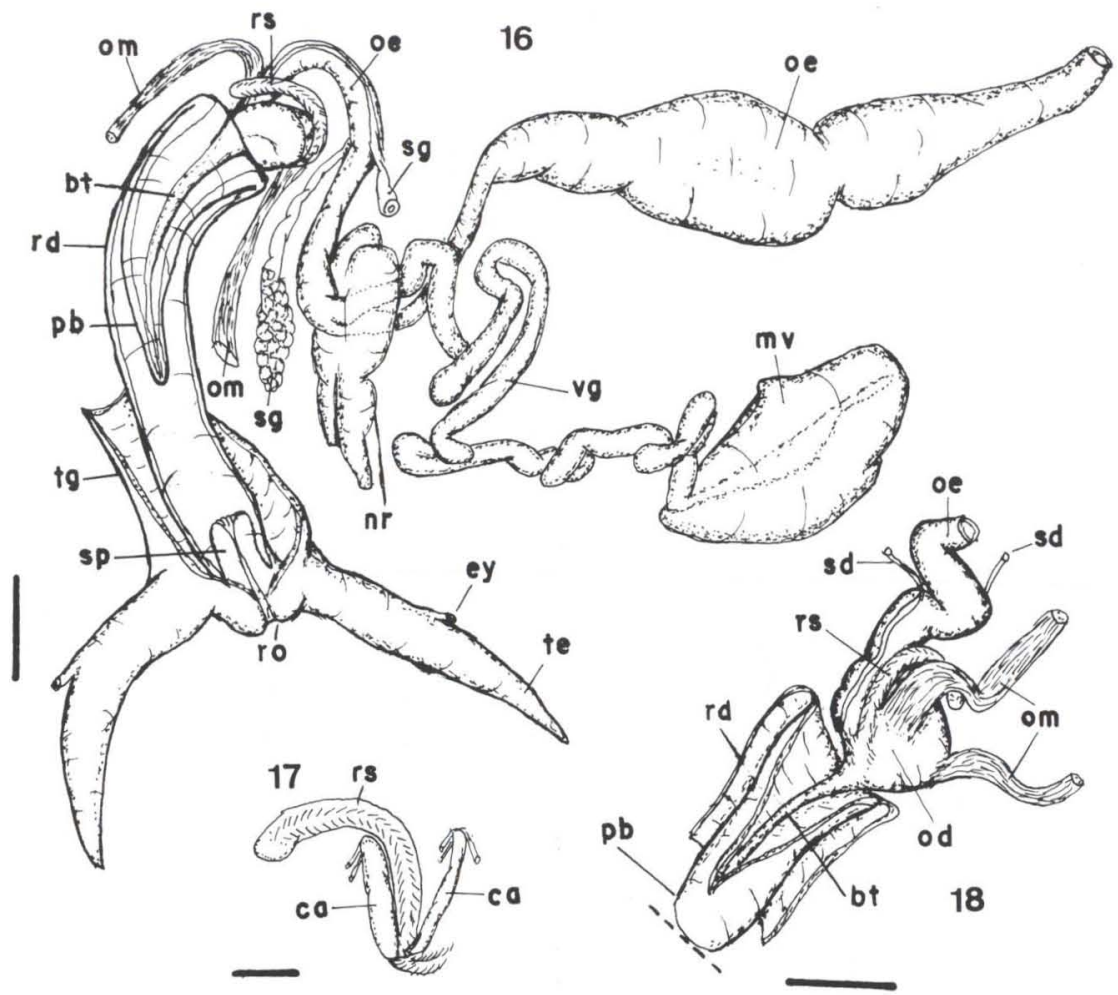

Figs 16-18. Cochlespira elongata anatomy. (16) Ventral view of the anterior region of the digestive system and head, scale: $0.5 \mathrm{~mm}$; (17) extracted radular sac and odontophore cartilages, dorsal view, horizontal muscle extracted, scale: $200 \mu \mathrm{m}$; (18) detail of the buccal mass, proboscis wall opened, ventral view, scale: $0.5 \mathrm{~mm}$.

Head-Foot. Uniformly pale-cream in colour. Foot of moderate size, without divisions (Fig. 11). Head bearing long and narrow tentacles (Figs 11, 12). Eyes dark on small protuberances of outer side and slightly over tentacle's base. Rhynchostome a longitudinal slit (Fig. 12). Male with proportional large penis behind right tentacle (Fig. 11), curved backwards in pallial cavity.

Operculum. Yellowish-transparent, terminal nucleus, with a discrete projection in its upper margin (Fig. 13), occupies entire aperture. Scar elliptical, near inner margin.

Mantle border. Broad and thin; anal sinus in upper region (Fig. 15); a small outer fold, perpendicular to border, adjacent to keel (Fig. 15: ef). Siphon large, curved and slightly flattened, with smooth border (Fig. 15). Mantle border and siphon of uniform pale-cream colour.

Mantle cavity. About 1.5 whorls in length (Fig. 15). Rectum margins right border in males; on mid-ventral side of posterior region of pallial oviduct and left 
side of anterior region of the same in females. Anus with a long, narrow and sharp pointed papilla. Hypobranchial gland small, covering inner region of mantle between gill and rectum (or pallial oviduct of females). Gill long and narrow, with numerous tall, curved, sharp-pointed filaments, left margin of filaments convex and right margin concave (Fig. 14). Osphradium enormously developed, bipectinate, located at root of the siphon, has about 55 right and about 30 left filaments (Fig. 15); right filaments bilobed, with outer lobe larger and covered by gill (Fig. 14).

Digestive system. Rhynchostome walls thickened, bulging posteriorly within rhynchodeal cavity (Fig. 16: po); rhynchostomal sphicter in outer regions covering a nucleus of conjuntive tissue. No buccal lips. Rhynchodeal walls thin, bearing muscular fibers and free from haemocoel except in its anterior roof (Fig. 16); bears two muscular layers, an outer longitudinal and an inner circular. Proboscis well-developed, long and with thick walls, tapers towards rhynchodeal cavity. Buccal tube very-long and narrow (Figs 16, 18), opens at proboscis tip, with a very small sphicter. No gripping of tooth at proboscis tip. Odontophore oval, with two well-developed odontophore muscles, a pair of long and somewhat flattened cartilages (Fig. 17) and thin horizontal muscle. Radular sac long and curved, projected outside from odontophore, proportionally small. Radula (Fig. 9): rachidian small, base somewhat square, cusp central acuminate, spine-like; marginal tooth sharply pointed, somewhat elliptic, composed of two fused elements. Anterior esophagus in right side of buccal mass (Fig. 16). A pair of salivary glands sited near nerve ring, two ducts visible, lying attached from mid region of anterior esophagus to the buccal mass. No accessory salivary gland. Venom gland well-developed, convoluted, joins into esophagus in its middle region, just in region of nerve ring (Fig. 16), and not in buccal mass. Most part of venom gland with cells replete of micro-granules; in a short anterior portion becomes tubular with vacuoled cells. Muscular bulb welldeveloped, somewhat elliptic, with two layers of similar width. Posterior esophagus generally with three flattened chambers, compressed by muscular bulb; two anterior chambers with thin walls and internally smooth; posterior chamber with walls a little thickened and internally with longitudinal, narrow, low folds. Stomach poorly developed, with a posterior duct to digestive gland (Fig. 15), internally oblique folds.

Excretory-circulatory systems. Kidney and heart as normal neogastropod (Fig. 15), ventricle very developed, anterior aorta differentiable until buccal mass.

Genital system.

Male. Spermoduct convoluted, sited behind pallial cavity. Prostate gland of moderate size, sited in posterior-right region of floor of pallial cavity (Fig. 15: pt), no communication between spermoduct and mantle cavity. Vas deferens, between prostate and roof of penis, a cylindrical, convoluted tube attached to floor of pallial cavity, near columellar muscle (Figs 20, 22). Penis very-large and cylindrical, seminal spermoduct runs through penis as shown by figure 22. Tip of penis with a peculiar arrangement of structures, internally a glandiform structure in such tip spermoduct opens (Figs 21-22). This glandiform structure surrounded by an inner preputial structure (Figs 21, 22: ip), which is also surrounded by a second and outer preputial structure (Figs 21, 22: op). Penis of immature specimens very small, flattened, with a small papilla in tip (Fig. 20). 


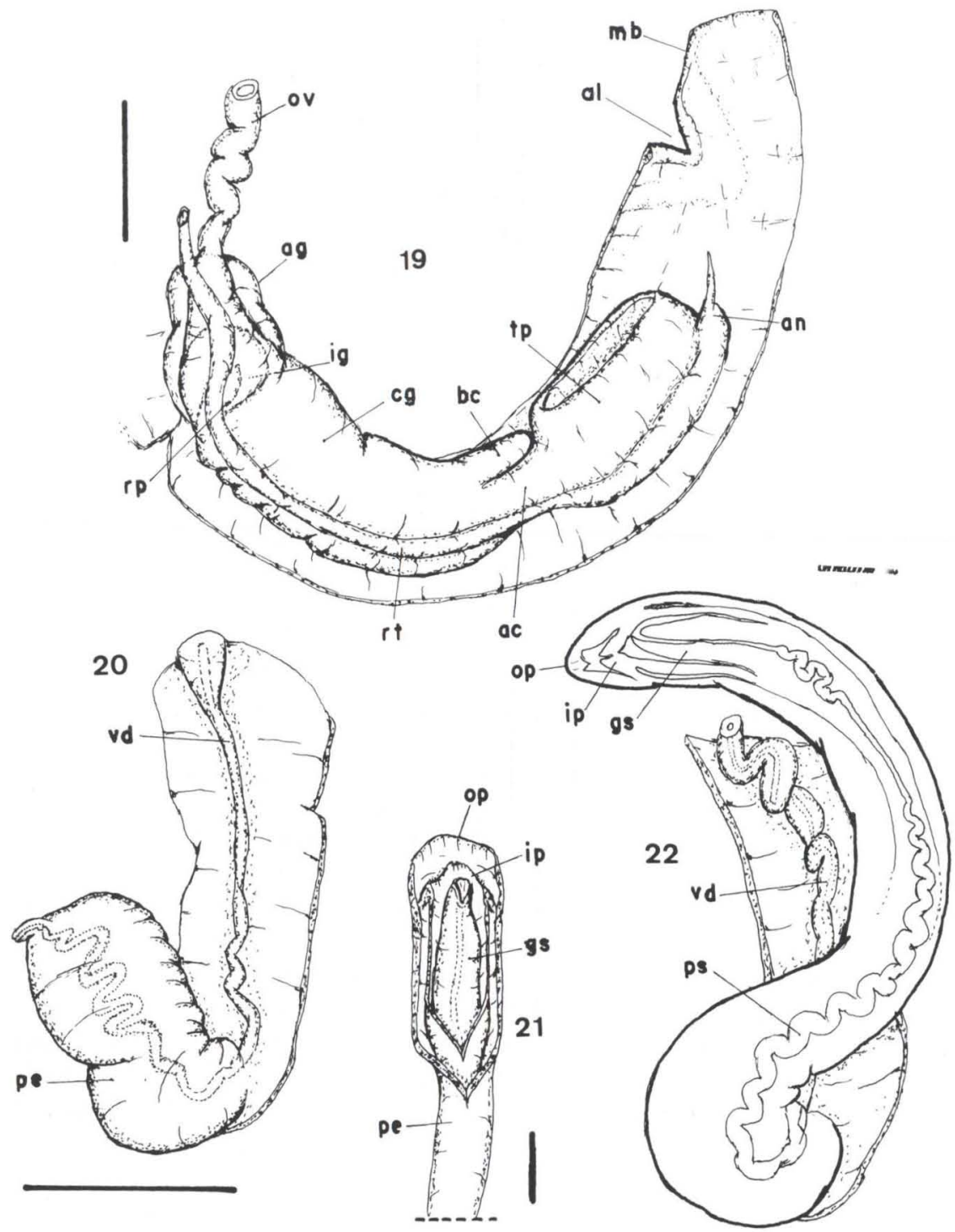

Figs 19-22. Cochlespira elongata anatomy. (19) Ventral view of the pallial oviduct and adjacent region of the pallial cavity; (20) penis and deferent of an immature male, dorsal view; (21) dissected distal region of a mature male penis; (22) general-dorsal view of a cleared mature pale penis and deferent; scales: $1 \mathrm{~mm}$.

Female. Oviduct runs near columella, a thick-walled and slightly convoluted tube. Oviduct, near anterior region of kidney, opens in a short and piriform albumen gland (Fig. 19). Between albumen and capsule glands a semi-sphaeric ingesting gland, attached to capsule gland by short and cylindrical receptaculum seminis. Capsule gland long, anteriorly limited at right by a short and sacciform bursa 
copulatrix, and at left by an aperture which communicates capsule gland with a well-developed terminal pouch. Aperture of terminal pouch a longitudinal slit, towards right (Fig. 19).
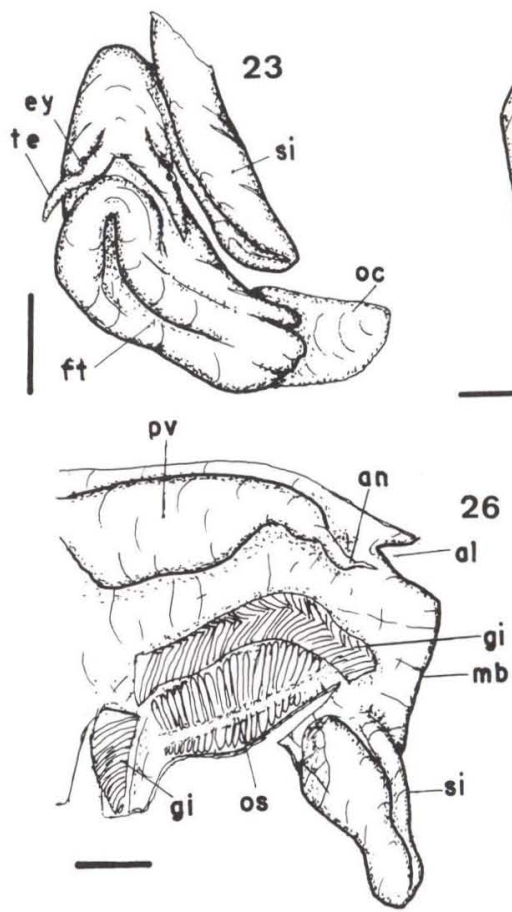
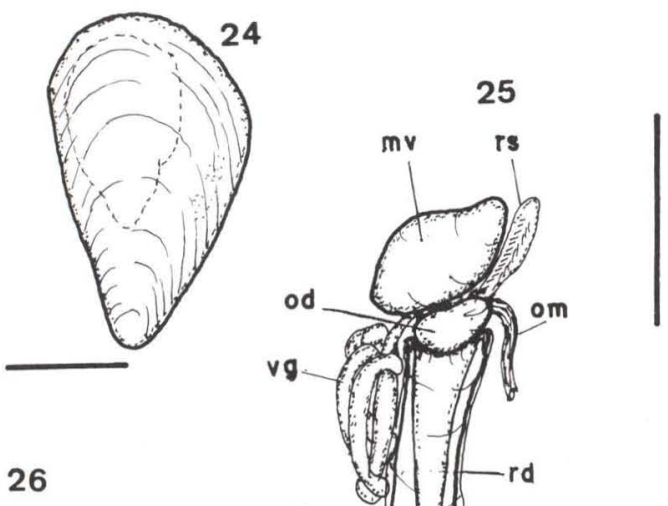

Figs 23-26. Cochlespira radiata, anatomy of rehydrated specimens. (23) Head-foot complex and siphon in frontal view; (24) operculum in external view; (25) detail of the anterior region of the digestive system, ventral view; (26) pallial organs, inner view; scales: $1 \mathrm{~mm}$.

Habitat. The specimens were collected on muddy and muddy-sand substrate. In type locality, exoskeletons of the coral Deltocyathus calcar (Verril) are very common. The depth varies from 250 to $350 \mathrm{~m}$, with one dead specimen found in $600 \mathrm{~m}$ (MZUSP 28118). RIOS (1975) referred 75 to $200 \mathrm{~m}$ depth for his studied stations. Brazil.

Distribution. Continental slope from Rio de Janeiro to Rio Grande do Sul,

Measurements. Holotype (MZUSP 28110) 17.0 by $6.5 \mathrm{~mm}$. Paratypes MZUSP 28111: 20.0 by $7.3 \mathrm{~mm}$; MZUSP 28112: 17.5 by $7.0 \mathrm{~mm}$; MZUSP 28113: 17.5 by $6.6 \mathrm{~mm}$. See also graph of the Fig. 27. There is a specimen, collected at $21^{\circ} 35^{\prime} \mathrm{S} 40^{\circ} 06^{\prime} \mathrm{W}, 248-262 \mathrm{~m}$ depth, in the Muséum National d'Histoire Naturelle, Paris, with $36.7 \mathrm{~mm}$ in length, maybe the largest known specimen.

Etymology. The specific epithet refers on the elongate shell shape (It. elongata). 


\section{Cochlespira radiata (Dall, 1889)}

Figs $3,4,6,8,10,23-27$

Ancistrosyrinx radiata Dall, 1889a: 78, pl. 12, fig. 12. 1889b: 96, pl. 12, fig. 12 [Cedar Keys, Florida]. - Dall \& Simpson, 1901 [Puerto Rico]. - Johnson, 1934: 135 [off Cape Florida; Gulf of Mexico]

- Warmke \& Abbott, 1961: 134, pl. 26, fig. q.. - Merrill \& Petit, 1969: 121. - Oliveira et. al., 1981:

274 [Gulf of Mexico].

Cochlespira radiata; Abbott, 1974, 265, fig. 2924. - Jong \& Coomans, 1988: 108.

Type locality. The syntypic series, sic DALL (1889a,b) comes from off Florida (Yucatan, Santa Cruz, Saba Bank, Santa Lucia, Cape Florida); near Martinique and off Barbados, from 45 to $315 \mathrm{~m}$ depth.

Diagnosis. Shell broader, length few more than two times the width; spines of keel turned outside; sculpture between posterior suture and keel a spiral lamella with both margins in a same plane; sculpture between keel and canal with two regions, that near keel with two or three spiral cords well spaced one another, that near canal a series of close and isometric spiral cords. Aperture moderately broad. Operculum without upper expansion.

Complementary description. Shell. Of mid size (to $18 \mathrm{~mm}$ ), elongate fusiform, with tall spire and long canal (Figs 3, 4), uniform yellowish in colour. Length few more than two times the width (length/width ratio=2.02-2.29-2.57) (Fig. 27). Protoconch of 1.5 glassy whorls (Fig. 6). Teleoconch up to 8 whorls, angulate by a keel initially in mid region of whorls (Fig. 6), gradually becoming proportionally near posterior suture (Figs 3,4). Sculpture between posterior suture and keel possessing a spiral, low, median lamella, more conspicuous in last whorls, with both margins in a same plane (Fig. 8), finishes in anal sinus of outer lip. Keel bearing short, triangular, flattened spines, somewhat regular spaced, turned outside and slightly upper (Figs 3, 4, 8), about 20 on body whorl. Sculpture between keel and canal (in body whorl) with two halves, that near keel with two or three spiral cords well spaced one another, that near canal a series of somewhat regular spiral cords close one another (Figs 3, 4, 8). Aperture slightly large and broad, about half of total spire length. Outer lip notched for a conspicuous anal sinus and keel. Inner lip covered by thin and glossy callus. Canal long, about same length as spire, rather straight and opened.

Head-foot. Foot of moderate size, without divisions (Fig. 23). Head bearing long and narrow tentacles (Figs 23, 25). Eyes dark, on small protuberances in outer side and slightly over tentacle base. Rhynchostome a longitudinal slit.

Operculum. Yellowish-brown, transparent, terminal nucleus, somewhat broad (Fig. 24), occupies entire aperture. Scar elliptic near inner margin. Without expansions.

Mantle border. Simple, with a conspicuous anal sinus (Fig. 26). Siphon large, curved, with smooth border (Figs 23, 26).

Pallial cavity (Fig. 26). Similar to that of C. elongata, osphradium large, bipectinate. Gill long with triangular and tall filaments. Pallial oviduct in right margin of cavity (without detail available). Anus siphoned, with a small pointed papilla in tip. 


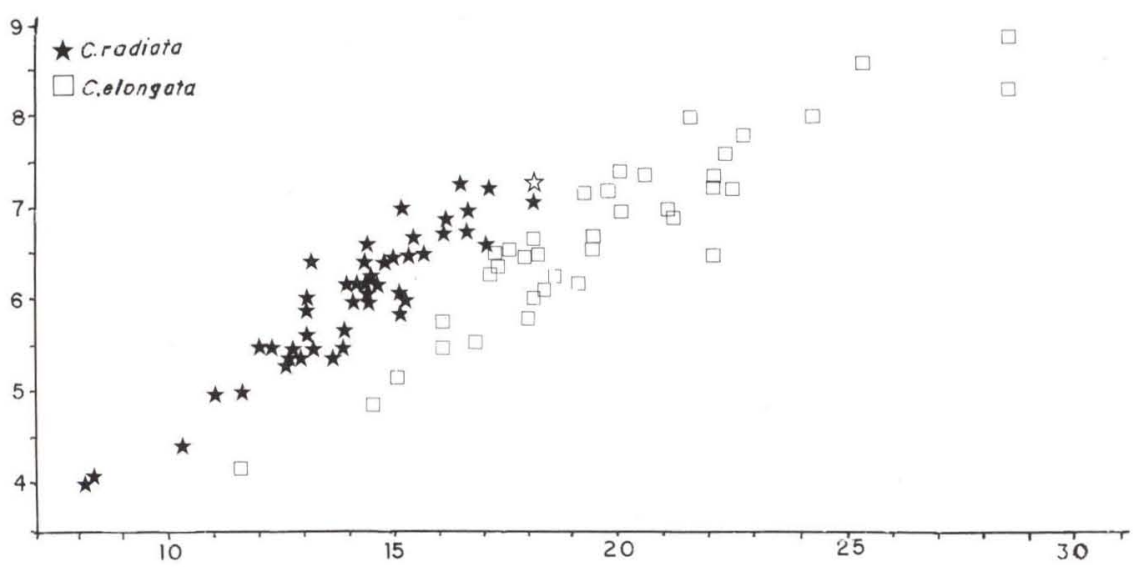

Fig. 27. Graph length $x$ width based on 46 specimens of Cochlespira radiata (stars) and on 38 specimens of $C$. elongata (squares). The white star is an approximation based on the measures given by DALL (1889a) for the figured specimen.

Digestive system. Is poorly preserved, but it is possible to observe a longitudinal rhynchostome, such walls has a large rhynchostomal sphincter bulging within rhynchodeal cavity (Fig. 25: po). Rhynchodeal walls free from haemocoel (Fig. 25), somewhat short. Proboscis tapers gradually within rhynchodeal cavity, inserts in a spherical buccal mass in which also inserts radular sac and esophagus. Radula very similar to that of $C$. elongata, but with marginal teeth with a longer tip (Fig. 10). Venom gland convolute. Muscular bulb elliptic.

Distribution. North Carolina to Florida, Gulf of Mexico and Caribbean Sea, from 45 to $315 \mathrm{~m}$ depth.

Material examined. United StATES of AMERICA, Florida: Henderson leg.; USNM 412324 (16 specimens), "Eolis" sta. 130, off Fowey Light, 45.5 m (1914); USNM 412296 (7 specimens); Miami, 82 m; USNM 412360 (41 specimens), "Eolis" sta. 185, off Fowey Light, 91 m. (1915); USNM 412359 (40 specimens) "Eolis" sta. 184, off Fowey Light, 87 m (1915); USNM 412341 (47 specimens) "Eolis" sta. 166, off Ragged Key, 120 m.

\section{DISCUSSION}

Cochlespira elongata has as closest species C. radiata (Dall, 1889a), differs in having: 1) larger size (length up to $37 \mathrm{~mm}$, in contrast, C. radiata has up to 18 $\mathrm{mm}$ ); 2) more elongate shell (the length/width ratio is 2.45-2.85-3.38, in contrast with the ratio of C. radiata: 2.09-2.29-2.57) (Fig. 27); 3) region between the posterior suture and the keel, of each whorl, with the spiral lamella marking a unevenness in the shell surface (while the spiral lamella in C. radiata has both margins in the same plane); 4) keel with spines turned upside (in contrast the keel of $C$. radiata has spines turned outside); 5) region between the keel and canal (in 
body whorl) with an uniform series of spiral cords, close one another (in contrast the cords near the keel of $C$. radiata are well spaced one another); 6) stronger sculpture; 7) narrower aperture; 8) operculum narrow and with an upper projection (while the operculum of $C$. radiata is broader, without projections).

On the soft parts, what was possible to compare with the dried (and posteriorly rehydrated) extracted specimens of C.radiata, there is close similarity between both species. The rhynchodaeum of $C$. radiata appear to be shorter and the anus is siphoned, while the anus of $C$. elongata is attached to the mantle. The marginal teeth of the radula have longer tip in C. radiata (compare Figs 9-10). DALL (1889a: 79) give a superficial soft parts data of C.radiata, difficult to be used in a more detailed comparison.

The distribution of $C$. radiata appear to be restrict to Northern waters, from N. Carolina, USA to Cuba (WARMKE \& ABBOTT 1961; ABBotT 1974), while the distribution of C. elongata appear to be restricted to Southeastern and South coast of Brazil (Rios 1975), from Rio de Janeiro to Rio Grande do Sul.

The foregut characters of the C. elongata are as normal Conoidea (sensu TAYLOR et. al. 1993), except by two aspects: 1) the rhynchodeal walls muscular and free from the haemocoel, resembling a pleurembolic proboscis, which also occurs in $C$. radiata, the presence of two layers of muscle allows some degree of functioning; 2 ) the venom gland inserting in mid region of the esophagus (near nerve ring) and not directly in the buccal mass, although, its histology appears to be typical Conoidea ( $c f$. TAYLOR et al. 1993: 145). The multidigitate osphradial leaflets and the well-developed rhynchostomal sphincter, bulging within the rhynchodeal cavity, is known in other Cochlespirinae (SYSOEV \& KANTOR 1987, 1988; TAYLOR et. al. 1993).

The female genital system of $C$. elongata is similar to that of Hastula cinerea (Born, 1778) ( $c f$. MARCuS \& MARCuS 1960, Fig. 16). In the mean time, the $C$. elongata male genital system has some distinctive characters in the penis. This has a complex arrangement of structures in the tip: one glandiform structure surrounded by two preputial structures (Figs 21,22). Although it is interesting to note that the penis of young specimens of C. elongata (Fig. 20) is somewhat similar to that of the adult $H$. cinerea ( $c f$. MARCUS \& MARCUS 1960, Fig. 14).

ACKNOWLEDGMENTS. I thank to M. Alan R. Kabat, Division of Mollusks, National Museum of Natural History, Smithsonian Institution, USA, for the loan of C. radiata specimens; Dr. John D. Taylor, Natural History Museum, London, for suggestive reading and comments on foregut anatomy; Prof. Dr. Ana Maria Vanin of IOUSP for the C. elongata specimens; Marcio V. Cruz of Instituto de Biociências, USP in helping SEM exam of specimens. This study is funded by the "Fundação de Amparo à Pesquisa do Estado de São Paulo" (FAPESP) research grant \#96/06756-2.

\section{REFERENCES}

AвBOTt, R.T. 1974. American Sea Shells, second edition. New York, Van Nostrand Reinhold Co., 663p. 
DALL, W.H. 1881. Reports on the results of dredging, under the supervision of Alexander Agassiz, in the Gulf of Mexico, and in the Caribbean Sea, 1877-79, by the U.S. Coast Survey steamer "Blake". Bull. Mus. Comp. Zool. 9 (2): 33-144.

1889a. Reports on the results of dredging...Steamer "Blake". Report on the Mollusca pt. 2 on Gastropoda and Scaphopoda. Bull. Mus. Comp. Zool. 18: $1-492$.

1889b. A preliminary catalogue of the shell bearing marine mollusks and brachiopods of the Southeastern coast of the United States, with illustrations of many of the species. Bull. U.S. Nat. Mus. 37: 1-221.

DALL, W.H. \& C.T. Simpson. 1901. The Mollusca of Porto Rico. U.S. Fish Comm. Bull. for 1900 20: 351-524.

JoHnson, C.W. 1934. List of marine Mollusca of the Atlantic coast from Labrador to Texas. Proc. Boston Soc. Nat. Hist. 40 (1): 1-204.

JonG, K.M. \& H.E. CoOmANS. 1988. Marine gastropods from Curaçao, Aruba and Bonaire. Leiden, Brill, E.J. Ed., $261 \mathrm{p.}$

Marcus, E.B.R. \& E. Marcus. 1960. On Hastula cinerea. Bol. Fac. Fil. C. Let. Univ. São Paulo, Zoologia, 260 (23): 25-54.

Merril, A.S. \& R.E. Petit. 1969. Mollusks new to South Carolina: II. Nautilus $82(4): 117-122$.

Oliveira, M.P.; G.J.R. Rezende \& G.A. CAStro. 1981. Catálogo dos moluscos da Universidade Federal de Juiz de Fora. Juiz de Fora, MEC, Univ. Fed. Juiz de Fora, 520p.

Rios, E.C. 1970. Coastal Brazilian Seashells. Rio Grande, Fund. Univ. Rio Grande, 255p.

—. 1975. Brazilian Marine Mollusks Iconography. Rio Grande, Fund. Univ. Rio Grande, $331 \mathrm{p}$.

- 1985. Seashells of Brazil. Rio Grande, Fund. Univ. Rio Grande, 329p. $368 \mathrm{p}$.

TAYloR, J.D.; Y.I. KANTOR \& A.V. SysoeV. 1993. Foregut anatomy, feeding mechanisms, relationships and classification of the Conoidea (=Toxoglossa) (Gastropoda). Bull. Nat. Hist. Mus., Zoology Series, 59 (2): 125-170.

Sysoev, A.V. \& Y.I. KanToR. 1987. Deep-sea gastropods of the genus Aforia (Turridae) of the Pacific: species composition, systematics, and functional morphology of the digestive system. Veliger 30 (2): 105-126.

- 1988. Three new species of deep-sea molluses of the genus Aforia (Gastropoda, Toxoglossa, Turridae). Apex 3: 39-46.

Warmke, G.L. \& R.T. AвbotT. 1961. Caribbean Sea Shells. Narberth, Livingston Publ., 346p. 